
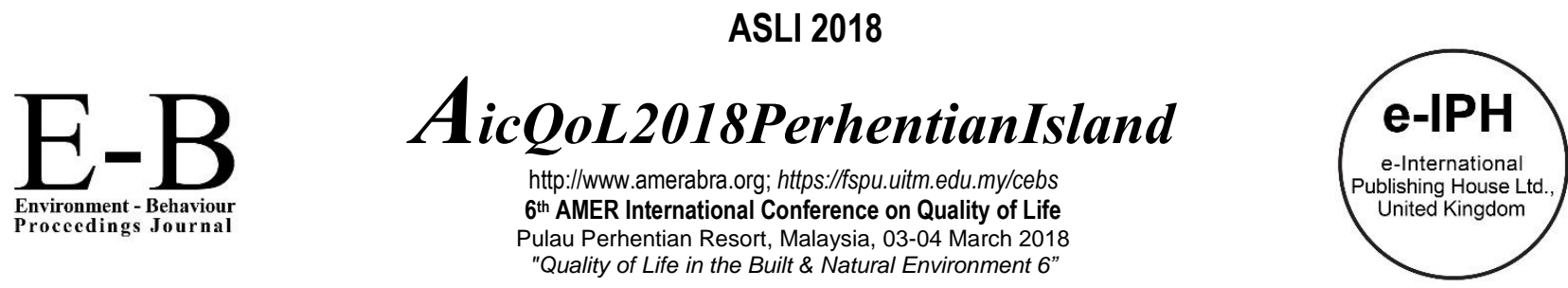

\title{
The Components of Social Dimension for Community Gardens in Housing Residential
}

\author{
Shafa Marzidah Abdullah Ayeop, Halmi Zainol, Nur Huzeima Mohd Hussain \\ Faculty of Architecture, Planning and Surveying, \\ Universiti Teknologi MARA, Perak Branch,32610, Seri Iskandar, Perak, Malaysia. \\ shafaayeop@gmailcom, halmizainol@gmail.com, nurhu154@perak.uitm.edu.my \\ Tel: +6013-5216695
}

\begin{abstract}
Community gardens are known as space for people to plant vegetables and fruits for their daily use. Various social benefits could be obtained through the implementation of community gardens in the urban neighbourhoods. This paper aims to give a better understanding relationship between the social dimension and community garden. The objectives of this paper are to identify the social dimension elements of sustainable development and to explore the benefits from community garden implementation towards social dimension. This paper analyses established references from previous articles and theses to identify a relationship between the social dimension and community garden.
\end{abstract}

Keywords: Community Garden; Social Dimension; Gardening Benefits; Sustainable

eISSN: 2398-42870 2018. The Authors. Published for AMER ABRA cE-Bs by e-International Publishing House, Ltd., UK. This is an open access article under the CC BYNC-ND license (http://creativecommons.org/licenses/by-nc-nd/4.0). Peer-review under responsibility of AMER (Association of Malaysian Environment-Behaviour Researchers), ABRA (Association of Behavioural Researchers on Asians) and cE-Bs (Centre for Environment-Behaviour Studies), Faculty of Architecture, Planning \& Surveying, Universiti Teknologi MARA, Malaysia.

DOI: https://doi.org/10.21834/e-bpj.v3i7.1253

\subsection{Introduction}

Sustainable development has been introduced to meet the current and future needs without neglecting aspects of economic, environmental and social needs (Brundtland, 1987). This concept aims to promote well-being through economic and social development to create a harmonious community (Abdul Halim, Mohammad Sukeri, \& Yusuf, 2013)). Sustainable development through social dimensions involves dealing with social problems by increasing economic productivity, improving human capital and reducing inequality to drive development outcomes towards sustainability (Unrisd, 2014). Globally, people are facing health problems such as malnutrition, obesity and depression. The number of malnourished people in the world increased from 777 million in 2015 to 815 million in 2016 (Food and Agriculture Organization of the United Nations, 2017). Studies in 2010 have shown the number of obese people is $774,000,000$ from $7,505,257,673$ which is equivalent to $10 \%$ of the world's population (Renew Bariatrics, 2018). According to World Health Organization (WHO) in 2017, there were more than 300 million people worldwide suffered from depression (WHO, 2018). Community gardens are considered as sustainable community development strategies and play a role in achieving social sustainability in the urban context (Jeffrey \& Alexander, 2004; Ohmer, Meadowcroft, Freed, \& Lewis, 2009). However, studies have shown numbers of issues related to the community gardens implementation such as lack of skill and knowledge regarding gardening activities and its advantages (Hallberg, 2009; Landry, Chittendon, Coker, \& Weiss, 2015; Filkobski, Rofè, \& Tal, 2016), lack of interest and commitment from communities (Saldivar-tanaka, Krasny, \& Hall, 2003; Rafiqah \& Aziz, 2015; Filkobski et al., 2016) and time constraints among communities make it difficult for them to engage in garden activities (Olawepo, 2012; Rateike, 2015; Rafiqah \& Aziz, 2015).

Recognizing the importance of social dimension and community gardens, this paper aims to give a better understanding relationship between social dimension and community garden implementation to improve community life to support sustainable development. The

eISSN: 2398-4287@ 2018. The Authors. Published for AMER ABRA cE-Bs by e-International Publishing House, Ltd., UK. This is an open access article under the CC BYNC-ND license (http://creativecommons.org/licenses/by-nc-nd/4.0/). Peer-review under responsibility of AMER (Association of Malaysian Environment-Behaviour Researchers), ABRA (Association of Behavioural Researchers on Asians) and cE-Bs (Centre for Environment-Behaviour Studies), Faculty of Architecture, Planning \& Surveying, Universiti Teknologi MARA, Malaysia.

DOI: https://doi.org/10.21834/e-bpj.v3i7.1253 
objectives are to identify the social dimension elements of sustainable development and to explore the benefits from community garden implementation towards social dimension. This paper analyses established references from previous articles and theses in orders to identify the relationship between the social dimension and community garden.

\subsection{Literature Review}

\subsection{The Components of Social Dimension}

Social sustainability is regarded as a place for communities to meet their needs today and in the future, protecting the environment and contributing to a better quality of life (Lupala, 2014). It is dealing with the process of enhancing the quality of life and community wellbeing (McKenzie, 2004; Yahaya, Badaruddin, \& Singh, 2017). Social sustainable reflect a resilient system of community life (Ngah, 2007). Seven social dimension components for sustainable development have been identified from previous studies consists health (McKenzie, 2004; Littig \& Griessler, 2005; Murphy, 2012; Unrisd, 2014; Nevado-Peña, López-Ruiz, \& Alfaro-Navarro, 2015), security \& safety (Arsić, Mišić1, \& Prlinčević1, Mladen Radojković, 2004; Littig \& Griessler, 2005; Dempsey, Bramley, Power, \& Brown, 2011; Woodcraft, Caistor-Arendar, Hackett, \& Peter, 2012; Unrisd, 2014; Nevado-Peña et al., 2015; Eizenberg \& Jabareen, 2017), social cohesion/interaction (Malcoci, n.d.; Arsić et al., 2004; Littig \& Griessler, 2005; Unrisd, 2014; Nevado-Peña et al., 2015, sense of belonging (McKenzie, 2004; Dempsey et al., 2011; Woodcraft et al., 2012), leisure/recreation (McKenzie, 2004; Woodcraft et al., 2012), education and skill (Malcoci, n.d.; Arsić et al., 2004; Littig \& Griessler, 2005; Murphy, 2012; Unrisd, 2014) and political activities (McKenzie, 2004; Unrisd, 2014). Table 1 shows the summary of social dimension components.

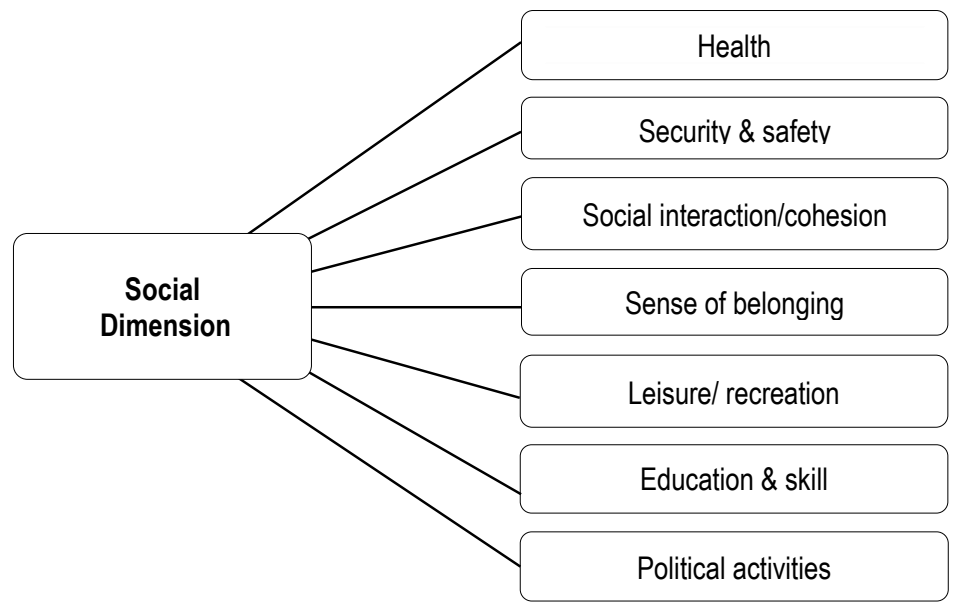

Fig. 1: Social Dimension of Sustainable Development

(Souce: McKenzie, 2004; Arsić, Mišić1, \& Prlinčević1, Mladen Radojković, 2004; Littig \& Griessler, 2005; Murphy, 2012; Unrisd, 2014; Nevado-Peña, López-Ruiz, \& Alfaro-Navarro, 2015; Eizenberg \& Jabareen, 2017)

\subsection{Community Garden}

The term community gardens refer to a piece of private or public land planted with food by a group of people (community) collectively in the neighbourhood for their daily use (Baldwin et al., 2009; Kearney, 2009; Smith \& Kurtz, 2010; JPBDSM \& KPKT, 2012; Okvat \& Zautra, 2011; Rateike, 2015). It involves with the cultivation of fruits, vegetables, flowers and herbs for own use and educational purposes (Smith \& Kurtz, 2010; Guitart, Pickering, \& Byrne, 2012; Victoria, Melody, \& El Shadan, 2016). Community gardens are managed and maintained voluntarily by non-profit oriented organizations (JPBDSM \& KPKT, 2012; ACGA, 2018). In summary, community gardens can be defined as a place in the neighbourhood planted with plants for local food supplies voluntarily carried out by non-profit organizations.

\subsection{Community Garden Benefits}

The establishment of community gardens contributes to the community well-being and social sustainability through strategic food planning to improve food safety and nutritional food intake. (Lovell, Husk, Bethel, \& Garside, 2014; Rafiqah \& Aziz, 2015). Community gardens are needed to address the food crisis and the socioeconomic issues of urban dwellers because of its potential as a catalyst for community development (Rasmuna Mazwan \& Mohd Rashid, 2015; ACGA, 2018). Based on previous studies, community gardens have shown a positive impact on community living from the 74 benefits identified through the enhancement of health, security/safety, social cohesion/ interaction, sense of belonging, leisure/ recreation, education \& skill, political activities elements. Each of community garden benefit is discussed below. 


\section{a. Health}

Previous studies have identified 17 health benefits from community gardens. It includes the increase food supply, improve access to fresh food, improve access to healthy food, improve access to medicinal herbs and flowers, offer variety of food, consume healthy diets, improve nutritionally balanced, reduce fast food consumption, increased consumption of fruits and vegetables, increase joy and happiness, increase feeling fresher, active \& more energetic, induce relaxation, reduce stress, fear and anger, reduce blood pressure, reduce muscle tension, reduce obesity and chronic diseases and provides physical exercise. Therefore, it has been proven that community gardens have improved the physical and mental health of the community through physical activity and balanced diet. Table 1 shows the summary of health benefits of community gardens.

Table 1: Summary of health benefits of community garden from literature

Health Benefits of Community References
Garden

1. Increase food supply

2. Improve access to fresh food

3. Improve access to healthy food

4. Improve access to medicinal herbs and flowers

5. Offer variety of food

6. Consume healthy diets

7. Improve nutritionally balanced

8. Reduce fast food consumption

9. Increased consumption of fruits and vegetables

10. Increase joy and happiness

11. Increase feeling fresher, active \& more energetic

12. Induce relaxation

13. Reduce stress, fear and anger

14. Reduce blood pressure

15. Reduce muscle tension
(Gulick, 2007); (Kearney, 2009); (Adedeji \& Ademiluyi, 2009); (Flachs, 2010); (Allison, Solana, \& Rebecca, 2012);

(Rezai, Shamsudin, Mohamed, \& Sharifuddin, 2014); (Martellozzo et al., 2014); (Yusoff, Hussain, \& Tukiman, 2017); (Martin \& Vold, 2018)

(Gulick, 2007); (Kearney, 2009); (Corrigan, 2011); (Jones, 2012); (Poulsen et al., 2014); (Nicholas, Stephanie, \& Madhavappallil, 2015)

(Flachs, 2010); (Corrigan, 2011); (Rezai et al., 2014);

(Evans et al., 2015); (Yusoff et al., 2017); (Jettner, 2017);

(Seguin et al., 2017);

(Thompson, Corkery, \& Judd, 2009);

(Middle et al., 2014)

(Jeffrey \& Alexander, 2004); (Alaimo, Packnett, Miles, \&

Kruger, 2008); (Zick, Smith, Kowaleski-Jones, Uno, \&

Merrill, 2013); (Rezai et al., 2014)

(Hynes \& Howe, 2004); (Kearney, 2009); (Adedeji \&

Ademiluyi, 2009);

(Ellen K Barnidge et al., 2013); (Alger, Lucy, Marian, \& Leslie, 2016)

(Twiss et al., 2003); (Alaimo et al., 2008); (Allen, Alaimo,

Elam, \& Perry, 2008); (Barnidge et al., 2013); (Castro,

Samuels, \& Harman, 2013); (E. K. Barnidge et al., 2015);

(Seguin et al., 2017)

(Poulsen et al., 2014);

(Thompson et al., 2009) (Ellen K Barnidge et al., 2013)

(Bellows, Brown, \& Smit, 2003); (Thompson et al., 2009)

(Bellows et al., 2003); (Wakefield, Yeudall, Taron,

Reynolds, \& Skinner, 2007); (Lovell et al., 2014)

(Thornbush, 2015); (Soga, Kevin, \& Yamaura, 2017);

(O'Donnell, 2016)

(Bellows et al., 2003); (Thompson et al., 2009)

(Bellows et al., 2003) 
16. Reduce obesity and chronic diseases

17. Provides physical exercise
(Bellows et al., 2003); (Hynes \& Howe, 2004); (Zick et al., 2013); (Castro et al., 2013); (Lovell et al., 2014); (E. K. Barnidge et al., 2015); (Litt, Lambert, \& Glueck, 2017) (Bellows et al., 2003); (Hynes \& Howe, 2004); (Thompson et al., 2009); (Yusoff et al., 2017)

\section{b. Security/Safety}

Previous authors have discussed and identified three positive effects of community gardens on safety and security. Its include reducing crime, increase safety feeling and reduce negative behaviour. Community gardens have a significant positive impact on the safety and security through the improvement of the neighbourhood environment. Table 2 shows the summary of security/safety benefits of community gardens.

Table 2: Summary of security/safety benefits of community garden from literature

\begin{tabular}{lll}
\hline \multicolumn{2}{l}{ Security/Safety Benefits of Community Garden } & \multicolumn{1}{c}{ References } \\
\hline 1. & Reduce crime & (Bellows et al., 2003); (Hynes \& Howe, 2004); (Kearney, 2009); (Nicholas et al., \\
& $2015)$ \\
2. Increase safety feeling & (Thompson et al., 2009); (Teig et al., 2009); (Poulsen et al., 2014); (Middle et al., \\
3. Reduce negative behaviour & 2014) \\
\hline
\end{tabular}

\section{c. Social Interaction/ cohesion}

Community gardens contribute to enhancing social interaction cohesion in the neighbourhood through 11 benefits identified from previous researchers. The benefits are such as to create new social interactions, an opportunity for community gathering, improve people connection \& interaction in the neighbourhood, increase family involvement, improve adult and youth interaction, developed friendship, enhance the sharing spirit, decrease levels of anti-social behaviour, reduce feelings of isolation and alienation, develop cultural diversity and build strong social cohesion. It was proven that community gardens have a good impact to improve the community interaction and cohesion through gardening activities conducted together and often meet in the garden. Table 3 shows the summary of security/safety benefits of community gardens.

Table 3: Summary of Social Interaction/ cohesion benefits of community garden from literature

\begin{tabular}{|c|c|}
\hline $\begin{array}{l}\text { Social Interaction/ Cohesion Benefits of Community } \\
\text { Garden }\end{array}$ & References \\
\hline 1. Create new social interactions & (Jeffrey \& Alexander, 2004); (Glover, Parry, \& Shinew, 2005) \\
\hline 2. Opportunity for community gathering & $\begin{array}{l}\text { (Flachs, 2010); (Poulsen et al., 2014); (Lovell et al., 2014); (Nicholas et al., } \\
\text { 2015) }\end{array}$ \\
\hline $\begin{array}{l}\text { 3. Improve people connection \& interaction in } \\
\text { neighbourhood }\end{array}$ & $\begin{array}{l}\text { (Wakefield et al., 2007); (Kearney, 2009); (Imas \& Ruth, 2012); (Jones, } \\
\text { 2012); (Poulsen et al., 2014); (Nicholas et al., 2015) }\end{array}$ \\
\hline Increase family involvement & (Nicholas et al., 2015); (Martin \& Vold, 2018) \\
\hline Improve adult and youth interaction & (Kearney, 2009); (Allen et al., 2008) \\
\hline 6. Developed friendship & $\begin{array}{l}\text { (Glover et al., 2005); (Thompson et al., 2009); (Poulsen et al., 2014); } \\
\text { (Montgomery, Wesener, \& Davies, 2016) }\end{array}$ \\
\hline 7. Enhance sharing spirit & $\begin{array}{l}\text { (Bellows et al., 2003); (Jeffrey \& Alexander, 2004); (Thompson et al., } \\
\text { 2009); (Teig et al., 2009); (Algert, Baameur, \& Renvall, 2014); (Poulsen et } \\
\text { al., 2014) }\end{array}$ \\
\hline Decrease levels of anti-social behaviour & (Jeffrey \& Alexander, 2004) \\
\hline 9. Reduce feelings of isolation and alienation & (Scott-Tunstall, 2007) \\
\hline 10. Develop cultural diversity & $\begin{array}{l}\text { (Corkery, 2004); (Thompson et al., 2009); (Middle et al., 2014); (Yusoff et } \\
\text { al., 2017) }\end{array}$ \\
\hline 11. Build strong social cohesion & $\begin{array}{l}\text { (Hynes \& Howe, 2004); (Poulsen et al., 2014); (Lovell et al., 2014) (Badami } \\
\text { \& Ramankutty, 2015); (Crossan, Shaw, Cumbers, \& McMaster, 2015); } \\
\text { (Thornbush, 2015); (Thornbush, 2015) }\end{array}$ \\
\hline
\end{tabular}

\section{d. Sense of Belonging}

The establishment of community gardens has improved the sense of belonging involve with enhancing the feeling of community belonging and ownership (Corkery, 2004; Thompson et al., 2009; Kearney, 2009; Imas \& Ruth, 2012) and creates the sense of pride (Wakefield et al., 2007; Poulsen et al., 2014; Nicholas et al., 2015).(Martin \& Vold, 2018) Community gardens have shown benefits to enhance the community sense of belonging through cooperation among the communities. Table 4 shows the summary of the sense of belonging benefits of community gardens. 


\section{e. Leisure/ recreation}

Community garden contributes to leisure and recreation opportunity to the community by providing places for recreation and relaxation activities (Bartolomei et al., 2003; Hochberg, 2014; Flachs, 2010; Yusoff et al., 2017). Community gardens have shown a positive impact on leisure and recreation activities through the provision of space for gardening activities.

\section{f. Education \& Skill}

Community garden contributes to the development of education and skill. It have been identified through learning various technic and procedure of horticulture and planting, learning to respect for nature and environment, learn about sustainability and sustainable practices in urban life, widening nutrition and physical activity education, educate value of gardens, educate young generation with local and healthy food, improve practices and develop the knowledge base of community gardens, enhance local knowledge and selfreliance, enhance youth skill building, increase awareness about issues of food security and learning different cooking techniques and recipe. Community gardens have been viewed to improved education and skills of the community through gardening programs and activities. Table 6 shows the summary of education and skill benefits of community gardens.

Table 4: Summary of education and skill benefits of community garden from literature

\begin{tabular}{lll}
\hline \multicolumn{2}{c}{ Education \& Skill Benefits of Community Garden } & \multicolumn{1}{c}{ References } \\
\hline 1. Learning various technic and procedure of horticulture and & (Corkery, 2004); (Poulsen et al., 2014); (Cherry, 2015); (Gersky, \\
planting & 2015) \\
2. Learning to respect for nature and environment & (Cherry, 2015) \\
3. Learn about sustainability and sustainable practices in & (Nicholas et al., 2015) \\
urban life & (Twiss et al., 2003); (Brown-Fraser, Forrester, Rowel, \\
4. Widening nutrition and physical activity education & Richardson, \& Spence, 2015) \\
& (Saldivar-tanaka et al., 2003) \\
5. Educate value of gardens & (Bellows et al., 2003) \\
6. Educate young generation with local and healthy food & (Jeffrey \& Alexander, 2004) \\
7. Improve practices and develop the knowledge base of & \\
8. Enmmunity gardens & (Gulick, 2007) \\
9. Enhance youth skill building & (Kearney, 2009) \\
10. Increase awareness about issues of food security & (Corrigan, 2011) \\
11. learning different cooking techniques and recipe & (Kearney, 2009) (Hochberg, 2014) \\
\hline \multicolumn{2}{c}{ (Source: Developed by the authors) }
\end{tabular}

\section{g. Political Activities}

Community gardens have been contributed to the community political activities. It has been traced through creating the organized and efficient community association empowered to take action on a local level, broaden their spaces of political engagement and develop social leadership. The community gardens have a positive impact on improving political activities through community involvement in local affairs as well as administering and managing neighbourhood associations. Table 7 shows the summary of political activities benefits of community gardens.

Table 5: Summary of political activities benefits of community garden from literature

\begin{tabular}{lll}
\hline & Political Activities Benefits from Community Garden & \multicolumn{1}{c}{ References } \\
\hline 1. & Creating an organized and efficient community association & (Kearney, 2009); (Baker, 2010); (Ghose \& Pettygrove, 2015) \\
2. Empowered to take action on a local level & (Ghose \& Pettygrove, 2014); (Crossan et al., 2015) \\
3. & Broaden their spaces of political engagement & (Ghose \& Pettygrove, 2014) \\
4. & Develop social leadership & (Ghose \& Pettygrove, 2014) \\
\hline & (Source: Developed by the authors)
\end{tabular}

\subsection{Methodology}

The literature review has been conducted using a variety of relevance such as relevant journals, articles, theses, websites, guidelines and reports. It involves the words 'social dimensions', 'social sustainability', 'community garden', 'urban agriculture' and 'urban farming'. All relevant references are reviewed regarding the use of existing theories on definitions, concepts, methods and approaches. To obtain extensive literature studies, this study have collected 90 references from 2003 to 2018.

Authors have found the similar study conducted by (Victoria et al., 2016). It identified the roles of community garden towards well-being by categorizing community garden benefits into Nutritional Health Environment and Social Health Environment. But this paper intended to explains detail on benefits of community gardens related to seven components of social dimensions. The methodology for this paper involves the following stages:

Stage one: Identification of sustainable development

Knowledge of sustainable development and social dimension have been identified through relevant references comprising definitions, theories, elements, advantages and the implementation of this concept globally and locally. The components of the social dimension of sustainable development have been identified at this stage. Each component was examined to get a clear understanding. Seven 
components of social dimension were reviewed based on the role of supporting sustainable development involving health, security \& safety, social cohesion/interaction, sense of belonging, leisure/ recreation, education and skill and political activities

Stage two: Identification of community gardens and benefits

This stage involves the identification of community gardens definition and its benefits to the community. Benefits of community gardens that have been identified are collected and organized according to the category of social dimension components.

Stage three: Conceptualizing a theoretical framework of social dimension and community gardens

Further investigation has been conducted on each community garden benefit and its function to community social development. Social dimension components have been synthesized with the benefit of community gardens based on its contribution to each of the seven social components. The literature review on the significant relationship between social dimensions and community gardens has been demonstrated in the conceptual framework to give a clear picture and understanding.

The limitation of this paper is that most of the literature review obtained from previous studies overseas due to the limited information in this country. Therefore, it doesn't reflect the experience of community gardeners in this country.

\subsection{Findings and Discussion}

The analysis of literature reviews reveals the initial conceptual framework to provide a clear understanding of the relationship between social dimensions and community gardens. Community gardens could act as a catalyst to support sustainable development. A total of 49 community gardens benefits have been organized based on seven social dimension components. The classification of each component was grouped in the similar item of components. The health component consists of 17 benefits, security/safety component comprises three benefits, social cohesion/interaction contains of 11 benefits, sense of belonging involves one benefit, education and skill consist of 11 benefits and political activities have four benefits. Fig. 2 shows the conceptual framework relationship between the social dimension and community gardens.

Based on the conceptual framework, this paper discovered that community gardens contribute various positive impacts on the physical and mental health of the community. It provides healthier lifestyle through food intake and physical activity performed during gardening. Crime could be reduced, thereby enhancing the sense of security among the community through the implementation of community gardens in the neighbourhood. Gardening activities contribute to enhancing social interaction and cohesion as these activities help to connect people by strengthening cooperation among the community including the younger generation and adults. The enhancement of the sense of belonging among community from community garden implementation could be identified through the feeling part of the community and improve willingness to actively participate in every activity organized by the local community. Community gardens also have the significant contribution to the positive impact on increasing leisure and recreation activities through the provision of space for gardening activities. Community gardens contribute to the positive impact on the development of education and skills by educating and enhance awareness on sustainability at all ages. Components of political activity can be enhanced through community gardens as it can increase community involvement in local affairs. As a summary, the implementations of community gardens certainly have the positive and significant relationship with the social components of sustainable development. 


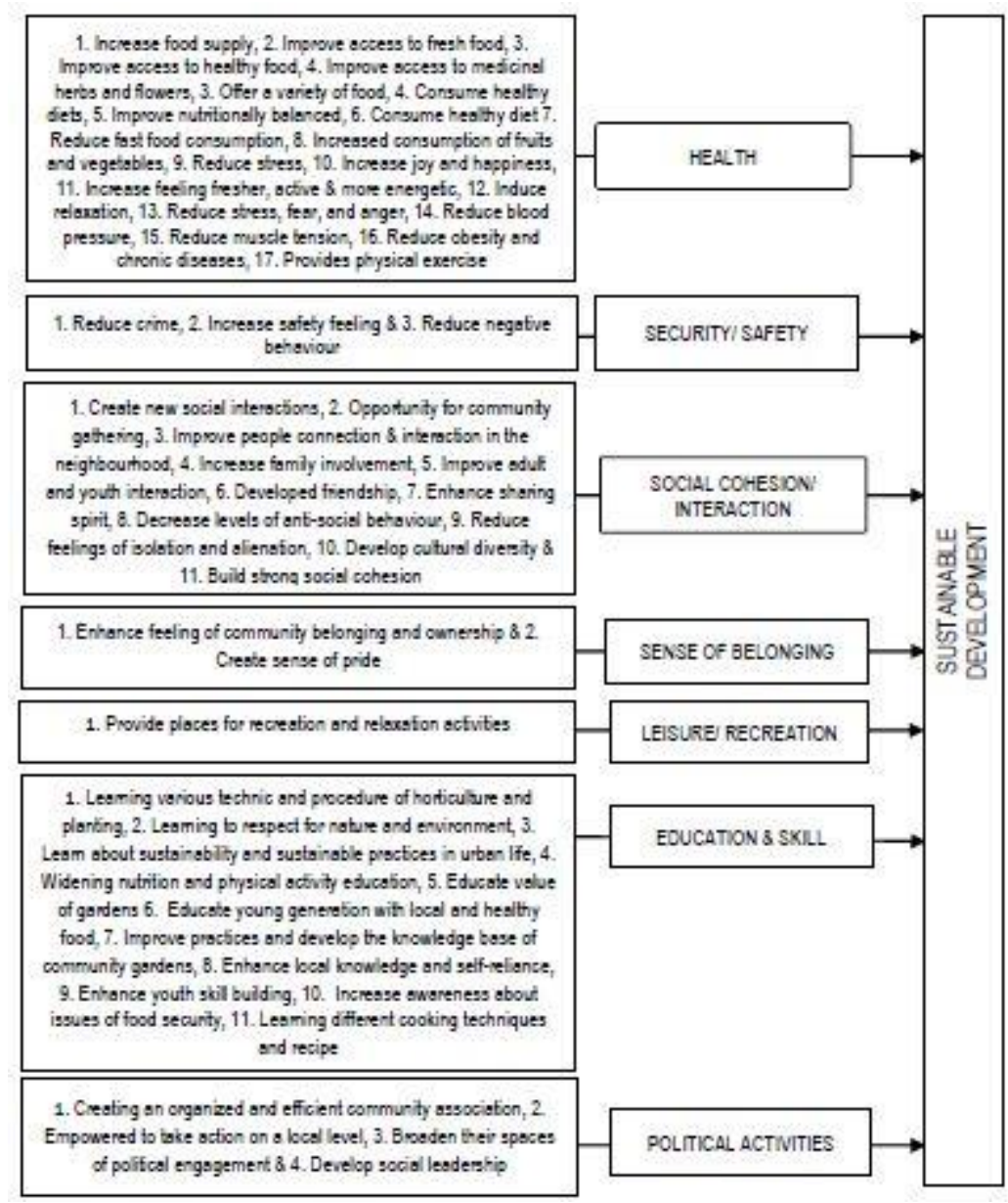

Fig. 2: Conceptual framework relationship social dimension and community gardens (Source: developed by the authors)

\subsection{Conclusion and Recommendation}

Community gardens offer a wide range of benefits to the well-being of the community. The proposed initial conceptual framework may contribute to a better understanding the relationship between social components of sustainable development and the benefits of the community garden. This paper is a scientific study that can be considered as a reference for researchers, urban planners, urban communities, community gardeners and stakeholders to enhance their knowledge of community gardens. It can also be used as a supporting document in consideration of the implementation of the community gardens. The authors have found that research and written documents of community gardens in this country are very limited. Therefore most of the literature was obtained from community gardens in overseas. This study believes many communities in this country refused to run community gardens due to the lack of knowledge and misunderstanding about community gardens. It is also possible due to lack of scientific research and evidence of existing community gardens in Malaysia.

Future research should study on the community gardeners experience in Malaysia to investigate the most significant benefit of the community garden and social components of sustainable development compare to the literature review that has been conducted. In this way, all the information to be obtained will be more significant and appropriate to be used as a reference to the local community in this country.

\section{Acknowledgements}

The authors are grateful and thankful the Centre of Postgraduate Studies, Universiti Teknologi MARA, Seri Iskandar Campus, Seri Iskandar for all the support and help towards this paper preparation. This paper also is an initial study of an on-going Masters research at the Faculty of Architecture, Planning and Surveying, UiTM.

\section{References}


Abdul Halim, A., Mohammad Sukeri, K., \& Yusuf, P. (2013). Ke Arah Pembangunan Mampan Setempat: Pelaksanaan Local Agenda 21 oleh Pihak Berkuasa Tempatan di Malaysia. Jurnal Pendidikan Sains Sosial Dan Kemanusiaan, 6(2), 209-222.

Adedeji, O. H., \& Ademiluyi, I. a. (2009). Urban agriculture and urban land use planning: Need for a synthesis in metropolitan Lagos, Nigeria. Journal of Geography and Regional Planning, 2(3), 043-050.

Alaimo, K., Packnett, E., Miles, R. A., \& Kruger, D. J. (2008). Fruit and Vegetable Intake among Urban Community Gardeners. Journal of Nutrition Education and Behavior, 40(2), 94-101. https://doi.org/10.1016/j.jneb.2006.12.003

Alger, S., Lucy, D., Marian, R., \& Leslie, G. (2016). Community and home gardens increase vegetable intake and food security of residents in San Jose, California. California Agriculture, 70(2), 77-82. https://doi.org/10.3733/ca.v070n02p77

Algert, S. J., Baameur, A., \& Renvall, M. J. (2014). Vegetable output and cost savings of community gardens in San Jose, California. Journal of the Academy of Nutrition and Dietetics, 114(7), 1072-1076. https://doi.org/10.1016/j.jand.2014.02.030

Allen, J. O., Alaimo, K., Elam, D., \& Perry, E. (2008). Growing vegetables and values: Benefits of neighborhood-based community gardens for youth development and nutrition. Journal of Hunger and Environmental Nutrition, 3(4), 418-439. https://doi.org/10.1080/19320240802529169

Allison, H., Solana, R., \& Rebecca, F. (2012). Growing Urban Agriculture : Equitable Strategies and Policies for Improving Access to Healthy Food and Revitalizing Communities. Oakland, California. Retrieved http://scholar.google.com/scholar?hl=en\&btnG=Search\&q=intitle:Growing+Urban+Agriculture+:+Equitable+Strategies+and+Policies+for+Improving+Access+to+Healthy + Food+and+Revitalizing+Communities\#0\%5Cnhttp://scholar.google.com/scholar?hl=en\&btnG=Search\&q=intitl

Arsić, A. K., Mišić1, M., \& Prlinčević1, Mladen Radojković, B. (2004). Social Aspects of Sustainable development of enterprise. 1st International Conference on Quality of Life, (June), 1155-1158. https://doi.org/10.1081/E-EPCS

Badami, M. G., \& Ramankutty, N. (2015). Urban agriculture and food security: A critique based on an assessment of urban land constraints. Global Food Security, 4, 815. https://doi.org/10.1016/j.gfs.2014.10.003

Baker, L. E. (2010). Tending Cultural Landscapes and Food Citizenship in Toronto'S Community Gardens. The Geographical Review, 94(3), 305-325. https://doi.org/10.1111/j.1931-0846.2004.tb00175.x

Baldwin, K., Beth, D., Bradley, L., Dave, N., Jakes, S., \& Nelson, M. (2009). Eat Move More North Carolina : Growing Communities. North Carolina. Retrieved from https://www.eatsmartmovemorenc.com/Gardens/Texts/ESMMGardens-LoRez.pdf

Barnidge, E. K., Baker, E. A., Schootman, M., Motton, F., Sawicki, M., \& Rose, F. (2015). The effect of education plus access on perceived fruit and vegetable consumption in a rural African American community intervention. Health Education Research, 30(5), 773-785. https://doi.org/10.1093/her/cyv041

Barnidge, E. K., Hipp, P. R., Estlund, A., Duggan, K., Barnhart, K. J., \& Brownson, R. C. (2013). Association between community garden participation and fruit and vegetable consumption in rural Missouri. International Journal of Behavioral Nutrition and Physical Activity, 10(1), 128. https://doi.org/10.1186/1479-5868-10-128

Bellows, A. C., Brown, K., \& Smit, J. (2003). Health Benefits of Urban Agriculture: Public Health and Food Security. North American Initiative on Urban Agriculture Committee, 19, 702-703. https://doi.org/10.2105/AJPH.19.6.702-b

Brown-Fraser, S., Forrester, I., Rowel, R., Richardson, A., \& Spence, A. N. (2015). Development of a Community Organic Vegetable Garden in Baltimore, Maryland: A Student Service-Learning Approach to Community Engagement. Journal of Hunger and Environmental Nutrition, $10(3)$, 409-436. https://doi.org/10.1080/19320248.2014.962778

Castro, D. C., Samuels, M., \& Harman, A. E. (2013). Growing Healthy Kids: A community garden-based obesity prevention program. American Journal of Preventive Medicine, 44(3 SUPPL. 3), S193-S199. https://doi.org/10.1016/j.amepre.2012.11.024

Cherry, L. S. (2015). Community Development At Heronswood Botanical Garden. UNIVERSITY OF NORTH TEXAS.

Corkery, L. (2004). Community Gardens as a Platform for Education for Sustainability. Australian Journal of Environmental Education, 20(1), 69-75. https://doi.org/10.1017/S0814062600002317

Corrigan, M. P. (2011). Growing what you eat: Developing community gardens in Baltimore, Maryland. Applied Geography, 31(4), $1232-1241$. https://doi.org/10.1016/j.apgeog.2011.01.017

Crossan, J., Shaw, D., Cumbers, A., \& McMaster, R. (2015). Glasgow's Community Gardens: Sustainable Communities of Care. Glasgow.

Dempsey, N., Bramley, G., Power, S., \& Brown, C. (2011). The social dimension of sustainable development: Defining urban social sustainability. Sustainable Development, 19(5), 289-300. https://doi.org/10.1002/sd.417

Eizenberg, E., \& Jabareen, Y. (2017). Social Sustainability: A New Conceptual Framework. Sustainability, 9(1), 68. https://doi.org/10.3390/su9010068

Evans, A., Banks, K., Jennings, R., Nehme, E., Nemec, C., Sharma, S., ... Yaroch, A. (2015). Increasing access to healthful foods: A qualitative study with residents of low-income communities. International Journal of Behavioral Nutrition and Physical Activity, 12(1), 1-12. https://doi.org/10.1186/1479-5868-12-S1-S5

Filkobski, I., Rofè, Y., \& Tal, A. (2016). Community gardens in Israel: Characteristics and perceived functions. Urban Forestry and Urban Greening, $17,148-157$. https://doi.org/10.1016/j.ufug.2016.03.014

Flachs, A. (2010). Food For Thought: The Social Impact of Community Gardens in the Greater Cleveland ... Electronic Green Journal, (30), 1-10.

Food and Agriculture Organization of the United Nations. (2017). The State of Food Security and Nutrition in the World. FAO. Retrieved from http://www.fao.org/state-of- 


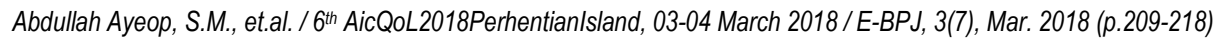

food-security-nutrition/en/

Gersky, K. (2015). Exploring Community Gardening: Motivations And Impacts. Wayne State University.

Ghose, R., \& Pettygrove, M. (2014). Urban Community Gardens as Spaces of Citizenship. Antipode, 46(4), 1092-1112. https://doi.org/10.1111/anti.12077

Ghose, R., \& Pettygrove, M. (2015). Actors and networks in urban community garden development Rina. Urban Forestry and Urban Greening, 17(4), 1-16. https://doi.org/10.1016/j.ufug.2015.07.001

Glover, T., Parry, D., \& Shinew, K. (2005). Mobilizing Social Capital in Community Garden Contexts.pdf. Journal of Leisure Research, 37, 450-474.

Guitart, D., Pickering, C., \& Byrne, J. (2012). Past results and future directions in urban community gardens research. Urban Forestry and Urban Greening, 11(4), 364373. https://doi.org/10.1016/j.ufug.2012.06.007

Gulick, M. (2007). Planning for community gardens: Local food systems for sustainable urban communities, (August).

Hallberg, B. (2009). Using Community Gardens to Augment Food Security Efforts in Low-Income Communities. Retrieved from http://www.ipg.vt.edu/Papers/Hallberg Major Paper.pdf

Hochberg, L. (2014). Urban Farm and Community Garden Hybrid Models : A Case Study of the Huerta del Valle Community Garden.

Hynes, H. ., \& Howe, G. (2004). Urban horticulture in the contemporary United States: person and community benefits. Acta Hort (ISHS), 643(171-181), 1-13. https://doi.org/10.17660/ActaHortic.2004.643.21

Imas, A., \& Ruth, B. (2012). Community Gardens: Space for Interactions and Adaptations. Procedia - Social and Behavioral Sciences, 36(June 2011), 439-448. https://doi.org/10.1016/j.sbspro.2012.03.048

Jeffrey, S., \& Alexander, I. (2004). Community Gardening in Perth : A Sustainable Planning Alternative, 2-6.

Jettner, J. F. (2017). Community gardens: Exploring race, racial diversity and social capital in urban food deserts. Virginia Commonwealth University. Retrieved from http://ovidsp.ovid.com/ovidweb.cgi?T=JS\&PAGE=reference\&D=psyc13\&NEWS=N\&AN=2017-33536-137

Jones, L. (2012). Improving Health, Building Community: Exploring the Asset Building Potential of Community Gardens. Evans School Review, 2(1), 66-84. Retrieved from https://depts.washington.edu/esreview/wordpress/wp-content/uploads/2012/12/ESR-2012-Improving-Health-Building-Community-Exploring-the-Asset-BuildingPotential-of-Community-Gardens.pdf

JPBDSM \& KPKT. (2012). Panduan Pelaksanaan Inisiatif Kejiranan Hijau-Pembangunan Kebun Kejiranan.

Kearney, S. C. (2009). The Community Garden as a Tool for Community Empowerment: A Study of Community Gardens in Hampden County. Masters Theses. University of Massachusetts. https://doi.org/10.1016/j.ufug.2015.07.001

Landry, A. S., Chittendon, N., Coker, C. E. H., \& Weiss, C. (2015). Perceived Effects of Community Gardening in Lower Mississippi Delta Gardening Participants. Journal of Extension, 53(4).

Litt, J. S., Lambert, J. R., \& Glueck, D. H. (2017). Gardening and age-related weight gain: Results from a cross-sectional survey of Denver residents. Preventive Medicine Reports, 8(October), 221-225. https://doi.org/10.1016/j.pmedr.2017.10.018

Littig, B., \& Griessler, E. (2005). Social sustainability: a catchword between political pragmatism and social theory. International Journal of Sustainable Development, 8(1/2), 65. https://doi.org/10.1504/IJSD.2005.007375

Lovell, R., Husk, K., Bethel, A., \& Garside, R. (2014). What are the health and well-being impacts of community gardening for adults and children: a mixed method systematic review protocol. Environmental Evidence, 3(1), 20. https://doi.org/10.1186/2047-2382-3-20

Lupala, J. M. (2014). The Social Dimension of Sustainable Development : Social Inclusion in Tanzania 's Urban Centres, (December), 350-360.

Malcoci, C. (n.d.). Social Dimensions Of Sustainable Development.

Martellozzo, F., Landry, J. S., Plouffe, D., Seufert, V., Rowhani, P., \& Ramankutty, N. (2014). Urban agriculture: A global analysis of the space constraint to meet urban vegetable demand. Environmental Research Letters, 9(6). https://doi.org/10.1088/1748-9326/9/6/064025

Martin, W., \& Vold, L. (2018). Building capacity through urban agriculture: report on the askîy project. Health Promotion and Chronic Disease Prevention in Canada, 38(1), 29-35. https://doi.org/10.24095/hpcdp.38.1.06

McKenzie, S. (2004). Social sustainability: Towards some definitions. Hawke Research Institute Working Paper Series, (27), 1-31. https://doi.org/10.1002/sres

Middle, I., Dzidic, P., Buckley, A., Bennett, D., Tye, M., \& Jones, R. (2014). Integrating community gardens into public parks: An innovative approach for providing ecosystem services in urban areas. Urban Forestry and Urban Greening, 13(4), 638-645. https://doi.org/10.1016/j.ufug.2014.09.001

Montgomery, R., Wesener, A., \& Davies, F. (2016). Bottom-Up Governance After A Natural Disaster: A Temporary Post-Earthquake Community Garden in Cental Christchirch, New Zealand. Nordic Journal of Architectural Research, 5(3), 143-173.

Murphy, K. (2012). The social pillar of sustainable development : a literature review and framework for policy analysis. Sustainability: Science, Practice, \& Policy, 8(1), 15-29. https://doi.org/10.1007/978-94-007-4854-5

Nevado-Peña, D., López-Ruiz, V.-R., \& Alfaro-Navarro, J.-L. (2015). The Effects of Environmental and Social Dimensions of Sustainability in Response to the Economic 
Crisis of European Cities. Sustainability, 7(7), 8255-8269. https://doi.org/10.3390/su7078255

Ngah, I. Bin. (2007). KOMUNITI MAP AN : PENILAIAN TAHAP KEMAP ANAN KOMUNITI ORANG ASLI TEMIAR DI NEGERI PERAK Abstract AN EVALUATION ON SUSTAINABILITY LEVEL OF ORANG ASLI. Jounial of the Afalaysian Lnstifllte of Plwmers, 113-129.

Nicholas, S., Stephanie, A., \& Madhavappallil, T. (2015). Building Sustainable Neighborhoods through Community Gardens : Enhancing Residents ' Well-being through University - Community Engagement Initiative. Metropolitan Universities, 26(1), 173-190.

O'Donnell, J. A. (2016). Community Gardens : Growing Control For Women Experiencing Food Insecurity In Food Deserts. Texas Woman's University.

Ohmer, M., Meadowcroft, P., Freed, K., \& Lewis, E. (2009). Community gardening and community development: individual, social and community benefits of a community conservation program. Journal of Community Practice, 17(4), 377-399 23p. https://doi.org/10.1080/10705420903299961

Okvat, H. A., \& Zautra, A. J. (2011). Community Gardening: A Parsimonious Path to Individual, Community, and Environmental Resilience. American Journal of Community Psychology, 47(3-4), 374-387. https://doi.org/10.1007/s10464-010-9404-z

Olawepo, R. A. (2012). Food Security and Challenges of Urban Agriculture in the Third World Countries.

Poulsen, M. N., Hulland, K. R. S., Gulas, C. A., Pham, H., Dalglish, S. L., Wilkinson, R. K., \& Winch, P. J. (2014). Growing an urban oasis: A qualitative study of the perceived benefits of community gardening in baltimore, maryland. Culture, Agriculture, Food and Environment, 36(2), 69-82. https://doi.org/10.1111/cuag.12035

Rafiqah, M., \& Aziz, A. M. (2015). Kepentingan pertanian bandar dan cabaran yang dihadapi oleh petani bandar di malaysia. International Journal of Environment, Society and Space.

Rasmuna Mazwan, M., \& Mohd Rashid, R. (2015). The Potential of Urban Farming Technology in Malaysia : Policy Intervention, 2011 (Figure 1), 1-5.

Rateike, A. (2015). Community Gardens in Knoxville: Insight into Challenges Facing Community Garden Initiatives. The University of Tennessee, Knoxville. Retrieved from http://trace.tennessee.edu/cgi/viewcontent.cgi?article=2905\&context=utk_chanhonoproj

Rezai, G., Shamsudin, M. N., Mohamed, Z., \& Sharifuddin, J. (2014). Factor influencing public participation in urban agriculture in Malaysia. International Journal of Social Science \& Human Behavior Study, 1(4), 55-58.

Saldivar-tanaka, L., Krasny, M. E., \& Hall, F. (2003). Culturing Community Development, Neighborhood Open Space, and Civic Agriculture: the Case of Latino Community Gardens in New York City.

Scott-Tunstall, C. N. (2007). The Social And Empowering Effect Of Community Gardens On A Chicago Urban Area (North Lawndale). Southern Illinois University Carbondale.

Seguin, R. A., Morgan, E. H., Hanson, K. L., Ammerman, A. S., Jilcott Pitts, S. B., Kolodinsky, J., ... McGuirt, J. T. (2017). Farm Fresh Foods for Healthy Kids (F3HK): An innovative community supported agriculture intervention to prevent childhood obesity in low-income families and strengthen local agricultural economies. BMC Public Health, 17(1), 1-20. https://doi.org/10.1186/s12889-017-4202-2

Smith, C. M., \& Kurtz, H. E. (2010). Community Gardens and Politics of Scale in New York City*. Geographical Review, 93(2), 193-212. https://doi.org/10.1111/j.19310846.2003.tb00029.x

Soga, M., Kevin, G., \& Yamaura, Y. (2017). Gardening is beneficial for health- A meta-analysis. Preventive Medicine Reports, 5, $92-99$.

Teig, E., Amulya, J., Bardwell, L., Buchenau, M., Marshall, J. A., \& Litt, J. S. (2009). Collective efficacy in Denver, Colorado: Strengthening neighborhoods and health through community gardens. Health and Place, 15(4), 1115-1122. https://doi.org/10.1016/j.healthplace.2009.06.003

Thompson, S., Corkery, L., \& Judd, B. (2009). The role of community gardens in creating healthy communities. Australian Planner, $161-171$. https://doi.org/10.1080/07293682.2009.9995307

Thornbush, M. (2015). Urban agriculture in the transition to low carbon cities through urban greening. AIMS Environmental Science, 2(3), 852-867. https://doi.org/10.3934/environsci.2015.3.852

Twiss, J., Dickinson, J., Duma, S., Kleinman, T., Paulsen, H., \& Rilveria, L. (2003). Community Gardens: Lessons Learned from California Healthy Cities and Communities. American Journal of Public Health, 93(9), 1435-1438. https://doi.org/10.2105/AJPH.93.9.1435

Unrisd. (2014). Social Drivers of Sustainable Development. Beyond 2015 Brief 04, (March 2013), 1-15.

Victoria, E., Melody, O., \& El Shadan, T. (2016). The development of a model of community garden benefits to wellbeing. Preventive Medicine Reports, 3, 348-352. https://doi.org/10.1016/j.pmedr.2016.04.005

Wakefield, S., Yeudall, F., Taron, C., Reynolds, J., \& Skinner, A. (2007). Growing urban health: Community gardening in South-East Toronto. Health Promotion International, 22(2), 92-101. https://doi.org/10.1093/heapro/dam001

Woodcraft, S., Caistor-Arendar, L., Hackett, T., \& Peter, S. (2012). Design for social sustainability new communities. Social Life, 54.

Yahaya, M. H., Badaruddin, R. F. R., \& Singh, P. S. J. (2017). Kesejahteraan Sosial dan Perumahan, 10(November), $245-256$.

Yusoff, N. H. B., Hussain, M. R. M., \& Tukiman, I. (2017). Roles of community towards urban farming activities. Planning Malaysia, 15(1), 271-278.

Zick, C. D., Smith, K. R., Kowaleski-Jones, L., Uno, C., \& Merrill, B. J. (2013). Harvesting more than vegetables: The potential weight control benefits of community gardening. American Journal of Public Health, 103(6), 1110-1115. https://doi.org/10.2105/AJPH.2012.301009 


\section{Website}

American Community Gardening Association (ACGA). "Growing Community Across the U.S. and Canada" Retrieved on Jan 18, 2018 from https://communitygarden.org/mission/

Renew Bariatrics "Report: Obesity Rates By Country - 2017"

Retrieved on Jan 19, 2018 from https://renewbariatrics.com/obesity-rank-by-countries/

World Health Organization (WHO) "Media Centre: Deepression"

Retrieved on Jan 19, 2018 from http://www.who.int/mediacentre/factsheets/fs369/en/

Roy, Montgomery, Andreas, Wesener Fran, Davies 